\title{
Regulation of insulin secretion: a matter of phase control and amplitude modulation
}

\author{
J. C. Henquin
}

Received: 21 November 2008 / Accepted: 5 February 2009/Published online: 14 March 2009

(C) Springer-Verlag 2009

\begin{abstract}
The consensus model of stimulus-secretion coupling in beta cells attributes glucose-induced insulin secretion to a sequence of events involving acceleration of metabolism, closure of ATP-sensitive $\mathrm{K}^{+}$channels, depolarisation, influx of $\mathrm{Ca}^{2+}$ and a rise in cytosolic free $\mathrm{Ca}^{2+}$ concentration $\left(\left[\mathrm{Ca}^{2+}\right]_{\mathrm{c}}\right)$. This triggering pathway is essential, but would not be very efficient if glucose did not also activate a metabolic amplifying pathway that does not raise $\left[\mathrm{Ca}^{2+}\right]_{\mathrm{c}}$ further but augments the action of triggering $\mathrm{Ca}^{2+}$ on exocytosis. This review discusses how both pathways interact to achieve temporal control and amplitude modulation of biphasic insulin secretion. First-phase insulin secretion is triggered by the rise in $\left[\mathrm{Ca}^{2+}\right]_{\mathrm{c}}$ that occurs synchronously in all beta cells of every islet in response to a sudden increase in the glucose concentration. Its time course and duration are shaped by those of the $\mathrm{Ca}^{2+}$ signal, and its amplitude is modulated by the magnitude of the $\left[\mathrm{Ca}^{2+}\right]_{\mathrm{c}}$ rise and, substantially, by amplifying mechanisms. During the second phase, synchronous $\left[\mathrm{Ca}^{2+}\right]_{\mathrm{c}}$ oscillations in all beta cells of an individual islet induce pulsatile insulin secretion, but these features of the signal and response are dampened in groups of intrinsically asynchronous islets. Glucose has hardly any influence on the amplitude of $\left[\mathrm{Ca}^{2+}\right]_{\mathrm{c}}$ oscillations and mainly controls the time course of triggering signal. Amplitude modulation of insulin secretion pulses largely depends on the amplifying pathway. There are more similarities than differences between the two phases of glucose-induced insulin
\end{abstract}

Adapted from the A. E. Renold Lecture 2008.

J. C. Henquin $(\bowtie)$

Unité d'Endocrinologie et Métabolisme, Faculty of Medicine,

University of Louvain,

UCL 55.30, Avenue Hippocrate 55,

1200 Brussels, Belgium

e-mail: jean-claude.henquin@uclouvain.be secretion. Both are subject to the same dual, hierarchical control over time and amplitude by triggering and amplifying pathways, suggesting that the second phase is a sequence of iterations of the first phase.

Keywords Amplifying pathway · Beta cell .

Biphasic insulin secretion - Cytosolic calcium .

$\mathrm{K}_{\mathrm{ATP}}$ channels · Oscillations · Potentiation · Sulfonylureas

\author{
Abbreviations \\ $\left[\mathrm{Ca}^{2+}\right]_{\mathrm{c}} \quad$ Cytosolic free $\mathrm{Ca}^{2+}$ concentration \\ $\mathrm{K}_{\text {ATP }}$ channel ATP-sensitive $\mathrm{K}^{+}$channel \\ SUR1 Sulfonylurea receptor 1
}

\section{Introduction}

Secreting insulin at the right moment and in appropriate amounts is the vital function of pancreatic beta cells. Any alteration of their functioning perturbs glucose homeostasis, leading to life-threatening hypoglycaemia when insulin secretion is excessive and to damaging hyperglycaemia whenever insulin secretion is insufficient. It is therefore not surprising that beta cells are under the tight control of an array of stimulatory and inhibitory factors, among which glucose plays the leading role through mechanisms that remain incompletely understood after more than 40 years of investigation [1-3].

All current models of stimulus-secretion coupling rightly feature beta cells as electrically excitable fuel sensors under hormonal and neural control. They emphasise the key role of ATP-sensitive $\mathrm{K}^{+}$channels ( $\mathrm{K}_{\text {ATP }}$ channels) for transduction of changes in glucose metabolism into changes in membrane potential, $\mathrm{Ca}^{2+}$ influx and cytosolic free $\mathrm{Ca}^{2+}$ concentration $\left(\left[\mathrm{Ca}^{2+}\right]_{\mathrm{c}}\right.$ ) (Fig. 1). Other reviews 
summarise the original work that elucidated this $\mathrm{K}_{\mathrm{ATP}}$ channel-dependent, triggering pathway more than 20 years ago [4-9], or discuss the multifactorial regulation of these complex channels composed of regulatory (sulfonylurea receptor 1 [SUR1]) and pore-forming (Kir6.2) subunits [10-12].

The more recent identification of an amplifying pathway, originally referred to as the $\mathrm{K}_{\mathrm{ATP}}$ channel-independent pathway $[13,14]$, has led to the proposal of a dual, hierarchical control of insulin secretion by glucose and other fuels $[8,15]$. Although this concept has progressively gained credit over the years, it has not yet been unanimously accepted and incorporated in all published models of the beta cell. The purpose of this review is to present recent experimental evidence supporting the physiological importance of the amplifying pathway and to discuss how both pathways complement each other to ensure temporal control and amplitude modulation of insulin secretion.

\section{The triggering pathway: essential for stimulating insulin secretion}

In the presence of non-stimulatory concentrations of glucose, the rate of metabolism in beta cells is relatively low and enough $\mathrm{K}_{\mathrm{ATP}}$ channels are open in the plasma membrane to counteract depolarising currents and maintain the membrane potential at values more negative than the threshold for opening the voltage-dependent $\mathrm{Ca}^{2+}$ channels. The influx of $\mathrm{Ca}^{2+}$ is minimal, $\left[\mathrm{Ca}^{2+}\right]_{\mathrm{c}}$ is low, and insulin secretion is basal. When the concentration of glucose increases, beta cell metabolism accelerates, leading to changes in the concentration of cytosolic adenine nucleotides (in particular an increase in ATP and a decrease in MgADP) which induce closure of $\mathrm{K}_{\text {ATP }}$ channels $[11,16]$. The resulting decrease in $\mathrm{K}^{+}$efflux causes membrane depolarisation, followed by opening of $\mathrm{Ca}^{2+}$ channels and $\mathrm{Ca}^{2+}$ influx into the cell (as reflected by the electrical activity shown in the inset of Fig. 1). The ensuing increase in $\left[\mathrm{Ca}^{2+}\right]_{\mathrm{c}}$ then activates an effector system that promotes exocytosis of insulin-containing granules [17-20]. The triggering $\mathrm{Ca}^{2+}$ signal is essential. All experimental conditions that interfere with the rise in $\left[\mathrm{Ca}^{2+}\right]_{\mathrm{c}}$ impair glucose-induced insulin secretion, whereas all agents, physiological or pharmacological, that increase beta cell $\left[\mathrm{Ca}^{2+}\right]_{\mathrm{c}}$ (regardless of the mechanism) induce insulin secretion $[8,21]$.

Two drugs that interact with the SUR1 subunit of $\mathrm{K}_{\mathrm{ATP}}$ channels $[10,22]$ have been particularly instrumental for the studies of stimulus-secretion coupling discussed below. Sulfonylureas, such as tolbutamide, mimic the action of glucose on membrane potential and $\mathrm{Ca}^{2+}$ influx, by closing

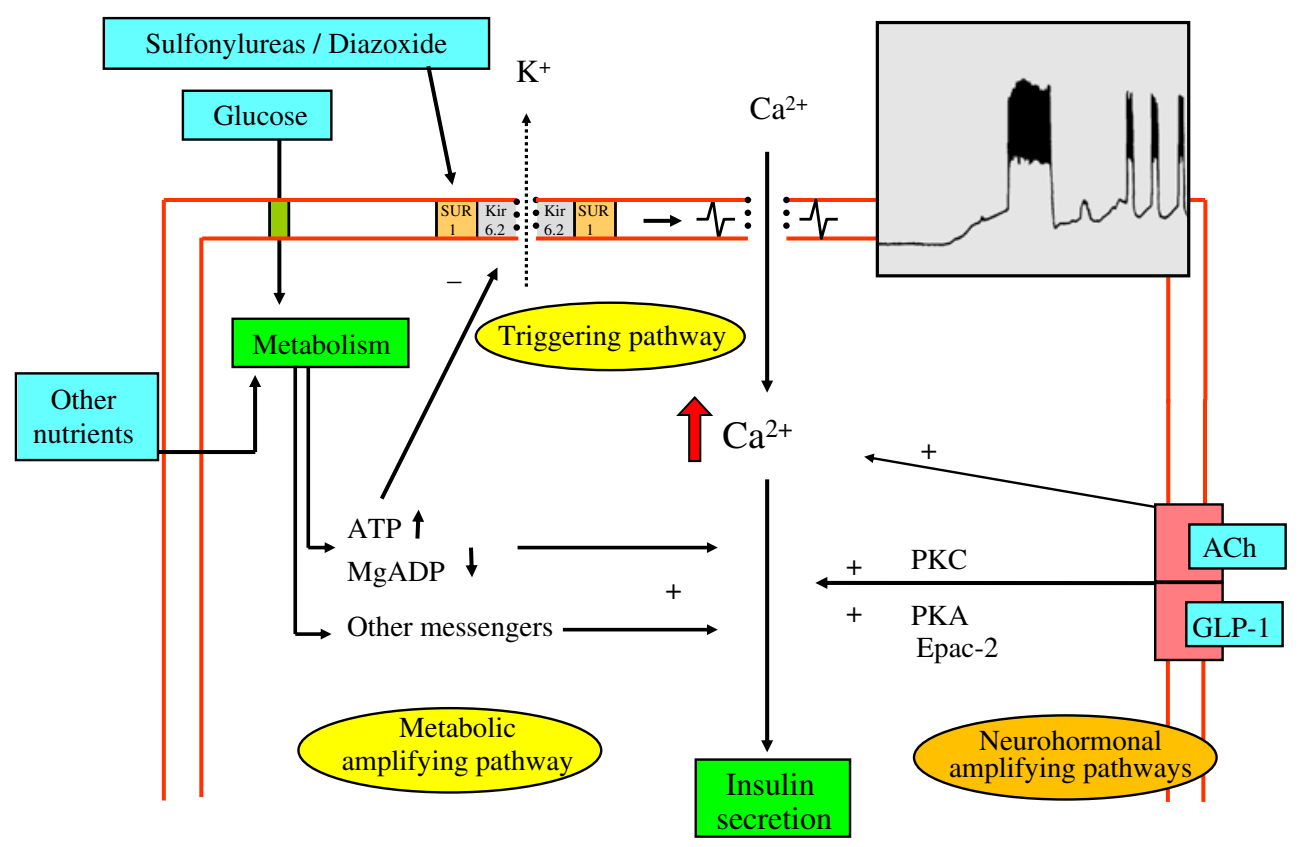

Fig. 1 Schematic representation of the triggering and metabolic amplifying pathways mediating the stimulation of insulin secretion by glucose, and of the neurohormonal amplifying pathways mediating the effects of neurotransmitters and hormones. The $\mathrm{K}_{\mathrm{ATP}}$ channel, made up of SUR1 and Kir6.2 subunits, is the transducer of metabolic changes into membrane potential changes. The inset illustrates the depolarisation and the electrical activity induced by glucose in one mouse beta cell within an intact islet; the recording was made with an intracellular electrode. The dotted line indicates a decreased flow. +, stimulation; -, inhibition; SUR1, sulfonylurea receptor 1; Kir, inwardly rectifying $\mathrm{K}$ channel; ACh, acetylcholine; Epac-2, exchange protein directly activated by cAMP 2; GLP-1, glucagon-like peptide 1; PKA, protein kinase $\mathrm{A}$; $\mathrm{PKC}$, protein kinase $\mathrm{C}$ 
$\mathrm{K}_{\mathrm{ATP}}$ channels independently of changes in metabolism. Conversely, diazoxide reverses the effects of glucose on membrane potential and $\mathrm{Ca}^{2+}$ influx through the direct opening of $\mathrm{K}_{\mathrm{ATP}}$ channels. Their respective stimulatory and inhibitory effects on insulin secretion are thus attributable to changes in the triggering $\mathrm{Ca}^{2+}$ signal (Fig. 1). Additional mechanisms have been proposed but are unlikely to contribute to the effects that sulfonylureas and diazoxide produce at therapeutically relevant concentrations [21]. Thus, both types of drug are inactive in beta cells lacking $\mathrm{K}_{\text {ATP }}$ channels because of a knockout of either Sur1 (Abcc8) [23, 24] or Kir6.2 (also known as Kcnj11) [25, 26].

\section{Revision of the model: evidence for an amplifying pathway}

While evidence supporting the essential role of $\mathrm{K}_{\mathrm{ATP}}$ channels in glucose-induced insulin secretion was accumulating, the possibility that glucose had additional, independent effects was expressed by investigators 20 years ago. One study showed that $15 \mathrm{mmol} / \mathrm{l}$ glucose alone induced a higher rate of insulin secretion than a combination of $10 \mathrm{mmol} / \mathrm{l}$ glucose and $5 \mu \mathrm{mol} / \mathrm{l}$ tolbutamide, although both conditions produced similar electrical activity and, presumably, a similar rise in $\left[\mathrm{Ca}^{2+}\right]_{\mathrm{c}}$ in beta cells. It was therefore proposed that non-electrogenic effects of glucose amplify insulin secretion [27]. Another study reported that glucose was able to increase insulin secretion in the presence of sulfonylurea concentrations sufficient to close all $\mathrm{K}_{\mathrm{ATP}}$ channels in beta cells, leading to the proposal that glucose was acting on other targets [28]. That glucose can influence insulin secretion independently of $\mathrm{K}_{\mathrm{ATP}}$ channels was directly established by two independent studies [13,14] that demonstrated the ability of glucose to increase insulin secretion from mouse or rat islets depolarised by $\mathrm{KCl}$ in the presence of diazoxide, i.e. when $\mathrm{K}_{\mathrm{ATP}}$ channels were held open pharmacologically. This effect of glucose was shown to depend on metabolism, to require elevated $\left[\mathrm{Ca}^{2+}\right]_{c}$ (by $\mathrm{KCl}$-induced depolarisation in these experiments), but was not found to involve a further rise in $\left[\mathrm{Ca}^{2+}\right]_{\mathrm{c}}[13,29]$. The increase in insulin secretion produced by glucose when $\mathrm{K}_{\mathrm{ATP}}$ channels are closed by saturating concentrations of sulfonylureas also occurs with little further increase in $\left[\mathrm{Ca}^{2+}\right]_{c}[8]$. The model of stimulussecretion coupling in beta cells was thus completed by the addition of a second pathway (Fig. 1) that I subsequently proposed to name 'the metabolic amplifying pathway' for reasons detailed in the textbox $[8,15]$. Pharmacological approaches similar to those described above have established that the amplifying pathway is also functional in pig [30] and human islets [31, 32], and in at least some insulin-secreting cell lines [33, 34]. In addition, glucose was recently reported to increase insulin secretion from mouse islets lacking $\mathrm{K}_{\mathrm{ATP}}$ channels, and the effect could be attributed, at least partly, to amplification of the triggering action of $\mathrm{Ca}^{2+}[24,26]$.

\section{Plea for a correct terminology}

The terms $\mathrm{K}_{\mathrm{ATP}}$ channel-dependent and $\mathrm{K}_{\mathrm{ATP}}$ channel-independent pathways are restrictive, often misleading and sometimes wrong. Several arguments support their substitution by triggering and amplifying pathways, a more simple and coherent terminology. First, an increase in beta cell $\left[\mathrm{Ca}^{2+}\right]_{\mathrm{c}}$ is sufficient to trigger insulin secretion, but is not necessarily $\mathrm{K}_{\mathrm{ATP}}$ channel-dependent. Unlike glucose, agents such as $\mathrm{KCl}$, acetylcholine, arginine or alanine depolarise beta cells and promote $\mathrm{Ca}^{2+}$ influx without acting on $\mathrm{K}_{\mathrm{ATP}}$ channels. Moreover, recent studies, in islets lacking $\mathrm{K}_{\mathrm{ATP}}$ channels because of a knockout of Sur1 [35] or Kir6.2 [26], suggest that glucose could also act via $\mathrm{K}_{\mathrm{ATP}}$ channel-independent mechanisms to depolarise beta cells and induce $\mathrm{Ca}^{2+}$ influx. Finally, mobilisation of intracellular $\mathrm{Ca}^{2+}$ can also increase $\left[\mathrm{Ca}^{2+}\right]_{\mathrm{c}}$. The term triggering pathway thus refers to the production of a single essential signal, a rise in $\left[\mathrm{Ca}^{2+}\right]_{c}$, regardless of the mechanism. Second, the adjective 'amplifying' clearly defines the hierarchy with the triggering pathway. In the absence of a triggering signal, amplification is functionally silent. During stimulation with glucose alone, the amplifying arm of the beta cell response is ineffective as long as the $\mathrm{K}_{\mathrm{ATP}}$ channel-dependent, triggering arm is not operative. Amplification is not directly, but indirectly, $\mathrm{K}_{\mathrm{ATP}}$ channel-dependent. This has been a source of major confusion. Third, the adjectives 'metabolic' and 'neurohormonal' distinguish two functionally similar, but mechanistically different, processes of augmentation of insulin secretion. The hierarchy with the triggering pathway is the same. Neurohormonal amplification, e.g. by acetylcholine or glucagon-like peptide 1 , is also ineffective if the triggering signal is not produced by high enough a concentration of glucose or by another stimulus. 


\section{Hierarchy of the triggering and amplifying pathways}

Glucose-induced insulin secretion is characterised by a sigmoidal concentration-dependence curve. The threshold (6-7 mmol/l in mouse islets) corresponds to the concentration at which enough $\mathrm{K}_{\text {ATP }}$ channels have been closed by glucose metabolism to permit depolarisation of the plasma membrane up to the electrical threshold where voltagedependent $\mathrm{Ca}^{2+}$ channels open, $\mathrm{Ca}^{2+}$ influx accelerates and $\left[\mathrm{Ca}^{2+}\right]_{\mathrm{c}}$ increases. Although glucose metabolism accelerates $[5,16]$ and amplifying signals are generated below this threshold $[8,29]$, insulin secretion remains basal until the triggering $\mathrm{Ca}^{2+}$ signal is produced. Increasing $\left[\mathrm{Ca}^{2+}\right]_{\mathrm{c}}$ by other means (membrane depolarisation with $\mathrm{KCl}$ or sulfonylureas) is sufficient to unmask the amplification exerted by at low-glucose concentrations. The supremacy of the triggering pathway is thus obvious (see $[8,15]$ for further discussion), but some confusion has stemmed from a paper reporting that glucose induced insulin secretion via a $\mathrm{K}_{\text {ATP }}$ channelindependent mechanism when $\left[\mathrm{Ca}^{2+}\right]_{\mathrm{c}}$ was artificially maintained at very low levels [36]. Such an effect of glucose indeed exists in vitro, but the extent of insulin secretion is negligible compared with that in the presence of normal $\left[\mathrm{Ca}^{2+}\right]_{\mathrm{c}}$, and the mechanism requires maximal stimulation of protein kinases $\mathrm{A}$ and $\mathrm{C}$ by pharmacological means [37]. It is of no physiological relevance and does not cast doubt on the hierarchy between triggering and amplifying pathways. Although switched on by lower glucose concentrations than those that produce depolarisation and $\mathrm{Ca}^{2+}$ influx, the amplifying pathway does not influence insulin secretion if $\left[\mathrm{Ca}^{2+}\right]_{\mathrm{c}}$ is not increased.

\section{The amplifying pathway under physiological conditions}

Because the experimental paradigms (either $\mathrm{KCI}$ plus diazoxide or a high sulfonylurea concentration) initially used to study the amplifying pathway in fact aimed to prevent an action of glucose on $\mathrm{K}_{\mathrm{ATP}}$ channels, concerns have been expressed that detection of the amplifying effects of glucose may require bypassing these channels. More specifically, doubts were raised concerning the physiological significance of the amplifying pathway. For these objections to be addressed, experiments were needed that did not involve the pharmacological clamping of beta cell $\left[\mathrm{Ca}^{2+}\right]_{\mathrm{c}}$, i.e. experiments that allowed $\left[\mathrm{Ca}^{2+}\right]_{\mathrm{c}}$ to fluctuate under the sole influence of the tested stimulus and quantitatively compared $\left[\mathrm{Ca}^{2+}\right]_{\mathrm{c}}$ with the rate of insulin secretion measured at the same time.

Insulin secretion and $\left[\mathrm{Ca}^{2+}\right]_{\mathrm{c}}$ were thus monitored in parallel in mouse islets stimulated by different concentrations of two non-metabolised agents, arginine and tolbutamide, in the presence of various glucose concen- trations [38]. The results showed that, in agreement with many previous studies, glucose potentiated insulin secretion induced by these non-metabolised secretagogues, but, further, demonstrated that this potentiation involves two mechanisms: augmentation of $\left[\mathrm{Ca}^{2+}\right]_{\mathrm{c}}$ and amplification of the response to $\mathrm{Ca}^{2+}$ [38]. These observations provided direct evidence in support of the conclusions of an electrophysiological study suggesting that glucose augments arginine-induced $\mathrm{Ca}^{2+}$ influx in beta cells and, by an unknown mechanism, also augments the efficacy of $\mathrm{Ca}^{2+}$ to stimulate insulin secretion [39]. This better understanding of the mechanisms by which glucose potentiates insulin secretion induced by non-metabolised secretagogues may help elucidate the pathogenesis of the alterations in insulin secretion in type 2 diabetic patients [40].

Further evidence for the physiological relevance of the amplifying pathway was obtained by comparing the increases in $\left[\mathrm{Ca}^{2+}\right]_{\mathrm{c}}$ and insulin secretion that occur in mouse islets stimulated by various glucose concentrations [41]. Average changes in $\left[\mathrm{Ca}^{2+}\right]_{\mathrm{c}}$ and insulin secretion produced by a rise in the glucose concentration from 3 up to either 11 or $30 \mathrm{mmol} / \mathrm{l}$ are illustrated in Fig. $2 \mathrm{a}$ and b. As shown in Fig. 2e, the glucose-dependency curves computed for second phase are sigmoidal, but the insulin response curve is shifted to the right as compared with the $\left[\mathrm{Ca}^{2+}\right]_{\mathrm{c}}$ response curve. This shift indicates that $\mathrm{Ca}^{2+}$ is not the only signal produced by glucose to stimulate second phase of insulin secretion under physiological conditions. It reflects metabolic amplification [41]. A similar conclusion was reached from the observation of a poor correlation between glucose-induced $\left[\mathrm{Ca}^{2+}\right]_{\mathrm{c}}$ rise and insulin secretion in dispersed islet cells [42].

While these studies provide evidence for the involvement of the amplifying pathway under physiological conditions, a mechanistic explanation of the phenomenon is still lacking. Although many possibilities have been tested and ruled out $[8,29,43,44]$, neither the second messenger nor the cellular effector has yet been unambiguously identified. Several approaches using intact or permeabilised cells have shown the involvement of ATP at steps of the secretory process distal to the $\left[\mathrm{Ca}^{2+}\right]_{\mathrm{c}}$ rise [45-47]. Adenine nucleotides may thus serve as second messengers in both pathways (Fig. 1), but other messengers could also be involved [8, 34, 48]. Recent studies call for a (re)evaluation of the roles of cAMP [49], NADPH [48, 50, 51], citrate cycle intermediates exported to the cytosol [48, 51, 52], AMP-activated protein kinase [53] and granule translocation by the cytoskeleton [18, 54]. Mathematical modelling of the amplifying pathway may also help to identify the effector system $[55,56]$. These issues will not be developed further in this review, to keep the focus on the interactions of the two pathways in the temporal control of insulin secretion. 
Fig. 2 Concentration dependency of biphasic changes in $\left[\mathrm{Ca}^{2+}\right]_{\mathrm{c}}$ and insulin secretion induced by glucose $(\mathrm{G})$ in mouse islets. a, b Perifused islets were stimulated by an increase in the glucose concentration from 3 to either 11 (normal trace, white circles) or $30 \mathrm{mmol} / \mathrm{l}$ (thick trace, black circles). For all tested glucose concentrations, increases in $\left[\mathrm{Ca}^{2+}\right]_{\mathrm{c}}$ (white circles) or insulin secretion (black circles) above baseline (in G3) are expressed as a per cent of the increase in $30 \mathrm{mmol} / \mathrm{l}$ glucose during the c initial peak within $3 \mathrm{~min}$ of stimulation $\left(K_{\mathrm{m}} 7.6\right.$ and $10.7 \mathrm{mmol} / 1$ for $\left[\mathrm{Ca}^{2+}\right]_{\mathrm{c}}$ and insulin, respectively); d integrated first phase over $7 \mathrm{~min}$ ( $K_{\mathrm{m}} 11.0$ and $\left.15.0 \mathrm{mmol} / \mathrm{l}\right)$; and $\mathbf{e}$ integrated second phase between 20 and $40 \mathrm{~min}$ $\left(K_{\mathrm{m}} 11.0\right.$ and $\left.16.3 \mathrm{mmol} / \mathrm{l}\right)$. The data, shown as means $\pm \mathrm{SE}$, are from [41]
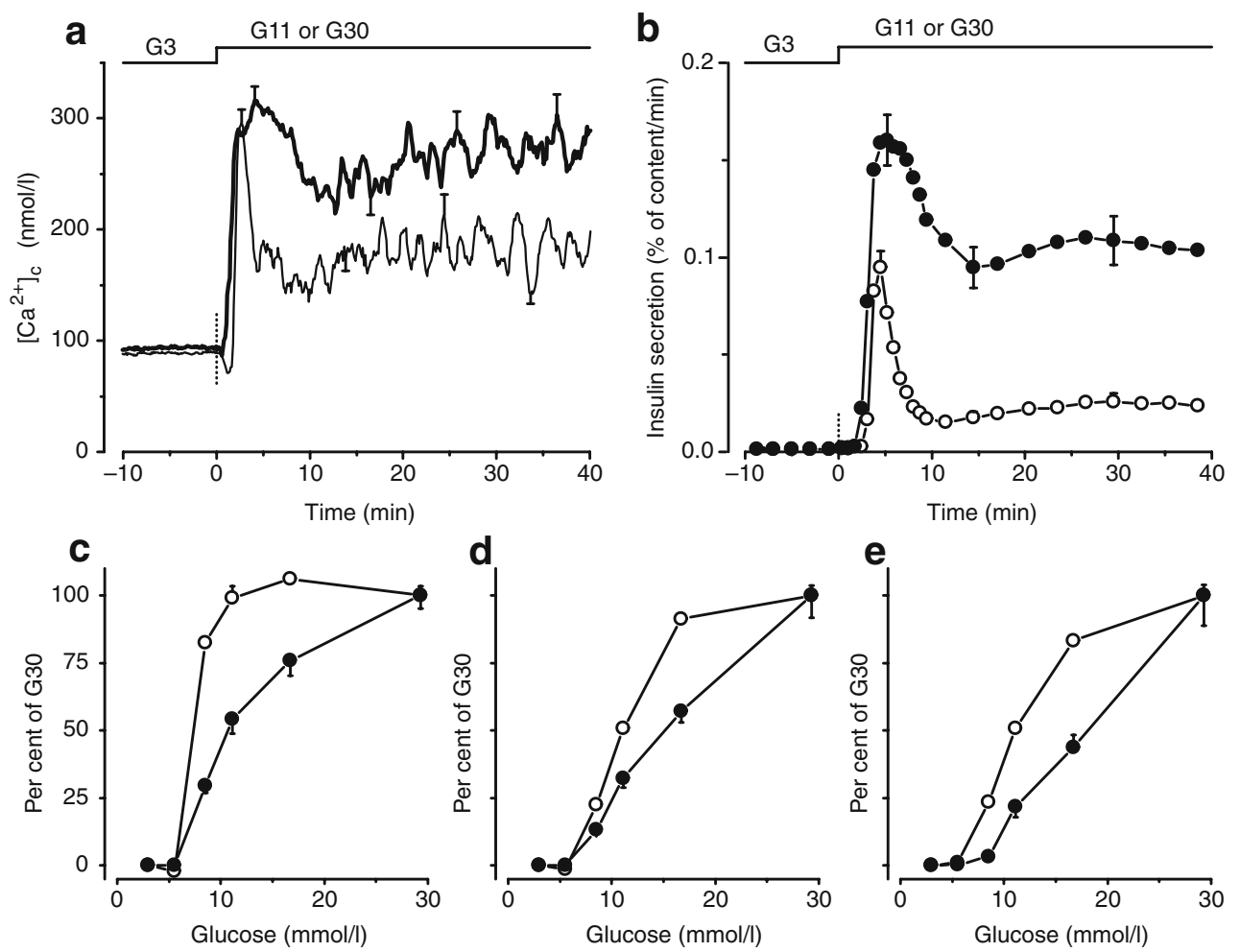

\section{The biphasic time course of glucose-induced insulin secretion}

Upon stimulation by an abrupt and sustained increase in the concentration of glucose, the rate of insulin secretion rapidly accelerates before slowing down (first phase), and eventually stabilises or progressively increases again (second phase) (Fig. 2b). This biphasic time course is observed in vivo and in vitro $[57,58]$, its characteristics varying somewhat with the experimental model and the species [59]. Notably, there is a discrepancy between in vivo and in vitro responses in mice and humans. Whereas plasma insulin levels increase during the second phase of a hyperglycaemic clamp [41, 60-62], second-phase insulin secretion is flat when islets of both species are studied in vitro $[32,41]$.

Interest in these peculiar biphasic kinetics has been fostered by numerous clinical studies showing that impaired first-phase insulin secretion in response to glucose is an early sign of beta cell dysfunction in type 2 diabetic patients [40, 57]. Two major, non-exclusive models have been proposed to explain the phenomenon at the islet/beta cell level (reviewed in [18, 34, 59, 61, 63]). One model is based on the distribution of insulin granules in different pools. It proposes that the first phase corresponds to the exocytosis of a small pool of 50-100 docked and primed (readily releasable) granules, whereas the second phase requires the translocation of granules from a reserve pool and their docking and priming. The second model suggests that the biphasic secretory response results from the biphasic time course of a single signal or of the sum of several stimulatory signals.

\section{The triggering pathway during the two phases of insulin secretion}

The triggering $\mathrm{Ca}^{2+}$ signal, produced via $\mathrm{K}_{\mathrm{ATP}}$ channeldependent depolarisation in normal beta cells, is essential for the first and second phases of glucose-induced insulin secretion. Both phases are abrogated when the $\left[\mathrm{Ca}^{2+}\right]_{\mathrm{c}}$ rise is prevented by omission of extracellular $\mathrm{Ca}^{2+}$ or by inhibition of depolarisation with diazoxide or inhibition of $\mathrm{Ca}^{2+}$ influx by blockage of voltage-dependent $\mathrm{Ca}^{2+}$ channels. Without disputing the essential role of L-type $\mathrm{Ca}^{2+}$ channels, it has been proposed that distinct channels variably contribute to $\mathrm{Ca}^{2+}$ influx during the two phases, and that $\mathrm{Ca}^{2+}$ entry through R-type $\mathrm{Ca}^{2+}$ channels creates the optimal conditions for granule translocation and priming during the second phase [64]. A contribution of intracellular stores to the rise in $\left[\mathrm{Ca}^{2+}\right]_{\mathrm{c}}$ during glucose stimulation is also possible [65], but the predominance of $\mathrm{Ca}^{2+}$ influx is indisputable. Whenever this influx is prevented, glucose lowers $\left[\mathrm{Ca}^{2+}\right]_{\mathrm{c}}$ in beta cells and insulin secretion is not stimulated. 


\section{The amplifying pathway during the two phases} of insulin secretion

Electrophysiological studies monitoring changes in beta cell membrane capacitance as a surrogate measurement of insulin secretion, and observations that non-metabolised agents reproduce first-phase better than second-phase insulin secretion have grounded the general idea that amplifying signals produced by glucose are necessary for the second phase but are not involved in the first phase, which is attributed to $\mathrm{Ca}^{2+}$-induced depletion of the pool of readily releasable granules $[18,34,54,66]$. The shift of the glucose-dependence curve for insulin secretion, compared with the curve for $\left[\mathrm{Ca}^{2+}\right]_{\mathrm{c}}$ changes (Fig. 2e), has already been described as evidence supporting the involvement of the amplifying pathway during the second phase. There is thus general agreement on this point. However, a similar shift exists for the peak of the first phase (Fig. 2c) or the whole first phase (Fig. 2d), which suggests that the amplifying pathway also contributes to the first phase [41]. This conclusion is supported by the results shown in Fig. $3 a$ and $b$. When mouse islets are challenged with $15 \mathrm{mmol} / \mathrm{l}$ glucose or with the maximally effective concentration of $500 \mu \mathrm{mol} / \mathrm{l}$ tolbutamide in $1 \mathrm{mmol} / \mathrm{l}$ glucose, the rise in $\left[\mathrm{Ca}^{2+}\right]_{\mathrm{c}}$ occurs more rapidly in response to the sulfonylurea than to glucose alone, but is of similar magnitude with both agents, both at onset and during steady-state stimulation (Fig. 3a). In contrast, insulin secretion (also more rapid with tolbutamide) is greater in response to glucose than tolbutamide during the first as well as the second phase (Fig. 3b). This difference is attributed to the activation of the amplifying pathway during glucose stimulation. My proposal that the amplification contributes to the first phase of glucose-induced insulin secretion may seem at odds with models attributing biphasic secretion to different pools of granules. It should be noted, however, that the exocytotic response (capacitance increase) of single beta cells to a first depolarisation is already augmented after 2-5 min in high glucose concentrations [46]. My suggestion is also in agreement with two $[67,68]$, though not all $[69,70]$, studies using imaging techniques to monitor exocytosis that concluded that granules released during both phases of glucose stimulation have a similar origin, distinct from the docked pool.

\section{Temporal control of first-phase insulin secretion by the triggering signal}

Figure 4a illustrates biphasic changes in $\left[\mathrm{Ca}^{2+}\right]_{\mathrm{c}}$ induced by $15 \mathrm{mmol} / \mathrm{l}$ glucose in four islets isolated from three different mice. The first phases of the $\left[\mathrm{Ca}^{2+}\right]_{\mathrm{c}}$ rise are similar in all islets, such that a well-defined first phase persists after averaging the responses from many islets (45 islets from five mice in Fig. 4b). The sudden change in glucose concentration acts as an extrinsic synchroniser. The simultaneous increase in the triggering signal in all beta cells is sufficient to induce first-phase insulin secretion in batches of islets (Figs $2 \mathrm{~b}$ and $3 \mathrm{~b}$ ) and probably also in a whole pancreas.

Comparison of the changes in $\left[\mathrm{Ca}^{2+}\right]_{\mathrm{c}}$ and insulin secretion induced by different glucose concentrations reveals another aspect of this time control (Fig. 2a, b). First phases not only increase in amplitude, they also increase in duration, and the similarity of the changes in $\left[\mathrm{Ca}^{2+}\right]_{\mathrm{c}}$ and secretion strongly suggests a causal relationship. Furthermore, imposed alterations in the kinetics of the initial elevation in $\left[\mathrm{Ca}^{2+}\right]_{\mathrm{c}}$ produced by glucose distort firstphase insulin secretion [59]. A striking example is illustrated in Fig. 3c. When mouse islets are stimulated simultaneously
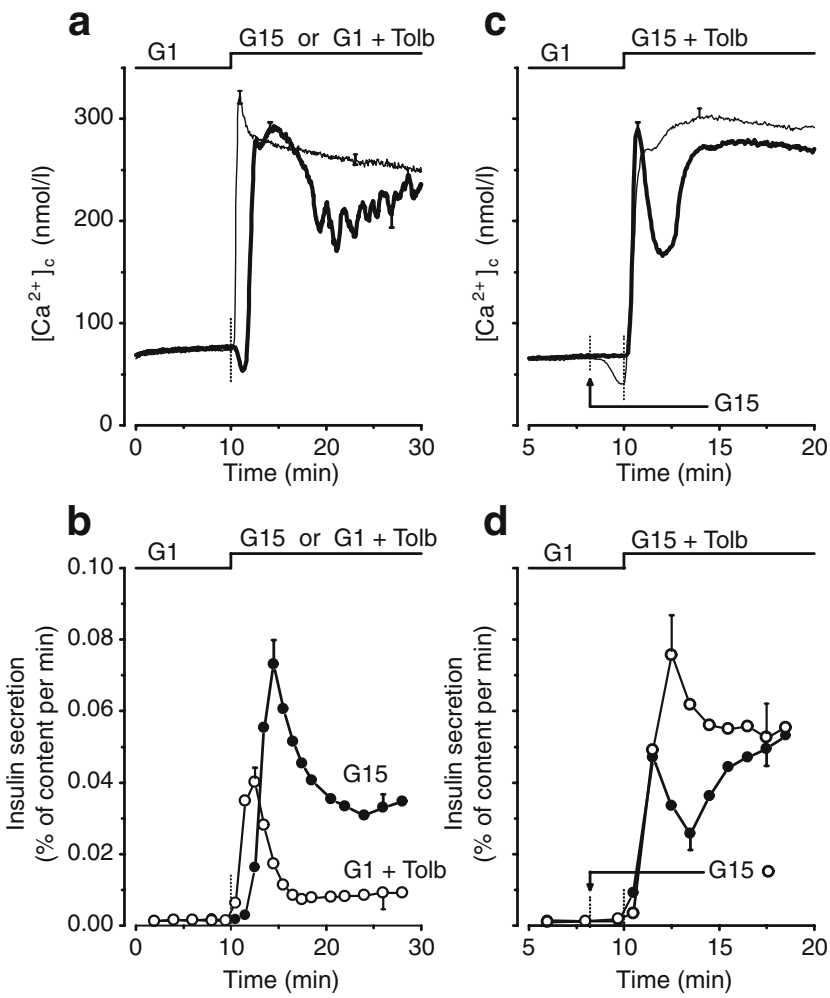

Fig. 3 Glucose- and tolbutamide-induced changes in $\left[\mathrm{Ca}^{2+}\right]_{\mathrm{c}}(\mathbf{a}, \mathbf{c})$ and insulin secretion $(\mathbf{b}, \mathbf{d})$ in mouse islets. All experiments started in the presence of $1 \mathrm{mmol} / 1$ glucose (G1). a, b The islets were stimulated by either G15 (thick trace, black circles) or $500 \mu \mathrm{mol} / 1$ tolbutamide (Tolb) in G1 (thin trace, white circles). c, d The islets were stimulated by the combination of G15 and tolbutamide. In one series (thick trace, black circles), both stimuli were added together at $10 \mathrm{~min}$. In the other series (thin trace, white circles) G15 was applied $100 \mathrm{~s}$ before tolbutamide, as shown by arrows. Note the different time scales in (c, d) vs $(\mathbf{a}, \mathbf{b})$. Values are means $\pm \mathrm{SE}$ for $40-45$ islets (five different mice) for $\left[\mathrm{Ca}^{2+}\right]_{\mathrm{c}}$, and for eight experiments of insulin secretion. Note that, for clarity, only some SE bars are shown 


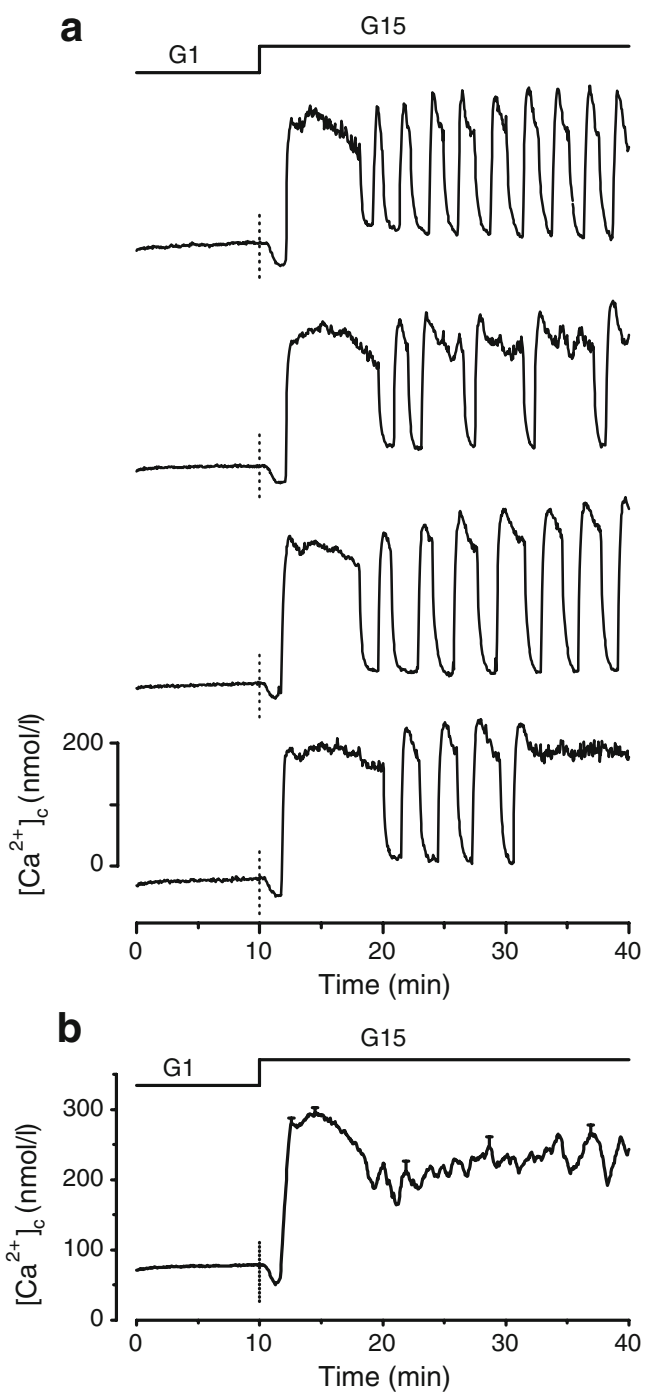

Fig. 4 Glucose-induced $\left[\mathrm{Ca}^{2+}\right]_{c}$ changes in mouse islets. The concentration of glucose $(\mathrm{G})$ was raised from 1 to $15 \mathrm{mmol} / \mathrm{l}$ as indicated at the top of each panel. a Responses of individual islets from three different mice; the third and fourth islets are from the same mouse. $\mathbf{b}$ Mean response $\pm \mathrm{SE}$ for 45 islets from five mice. Note that, for clarity, only some SE bars are shown

with $15 \mathrm{mmol} / \mathrm{l}$ glucose and $500 \mu \mathrm{mol} / \mathrm{l}$ tolbutamide, firstphase $\left[\mathrm{Ca}^{2+}\right]_{\mathrm{c}}$ rise is rapidly but transiently interrupted by a lowering that is reminiscent of the initial decrease in basal $\left[\mathrm{Ca}^{2+}\right]_{\mathrm{c}}$ produced by glucose alone (Fig. 3c). First-phase insulin secretion is brief, shorter than with either tolbutamide or glucose alone (Fig. 3d). This peculiar pattern was first observed in the perfused rat pancreas [71]. In contrast, when the stimulation with tolbutamide is applied $100 \mathrm{~s}$ after the increase in glucose concentration, at the end of the decrease in basal $\left[\mathrm{Ca}^{2+}\right]_{\mathrm{c}}$, neither first-phase $\left[\mathrm{Ca}^{2+}\right]_{\mathrm{c}}$ increase, nor firstphase insulin secretion is interrupted (Fig. 3c, d). Together, these results show that first-phase insulin secretion is shaped by the time course and duration of the triggering $\mathrm{Ca}^{2+}$ signal.

\section{Amplitude modulation of first-phase insulin secretion}

Needless to say, the first phase is diminished when severe depletion of insulin stores limits granule availability for release. In normal beta cells, the amplitude of first-phase insulin secretion appears to be controlled by both the magnitude of the triggering signal and the amplification of its action on exocytosis of insulin granules (Figs 2 and 3). This dual regulation and the temporal control that glucose also exerts (see preceding paragraph) indicate that the first phase is not attributable simply to the emptying of a limited pool of insulin granules. It is also noteworthy that peak first-phase insulin secretion in vitro is more sensitive to glucose than integrated first-phase secretion (area under the curve), the latter showing the same glucose dependence as second-phase secretion (Fig. 2). This may be important when comparing the two phases or when comparing the first phase between studies.

\section{Temporal control of second-phase insulin secretion by the triggering signal}

Second-phase insulin secretion, or total secretion in static measurements, is usually looked upon as a process subject to amplitude modulation, whereas its time regulation is often overlooked. We have seen above that the time dimension in the control of first-phase insulin secretion is not lost by averaging the responses from several islets. The situation is more complex during the second phase. Although the concentration of glucose is stable, the membrane potential of beta cells oscillates (Fig. 1 inset), generating oscillations of $\left[\mathrm{Ca}^{2+}\right]_{\mathrm{c}}$ (Fig. 4). Different types of $\left[\mathrm{Ca}^{2+}\right]_{\mathrm{c}}$ oscillations are known to occur in mouse islets stimulated by glucose. Their characteristics and possible mechanisms are discussed in other reviews [72-74]. In the present context, it is sufficient to emphasise that all these $\left[\mathrm{Ca}^{2+}\right]_{\mathrm{c}}$ oscillations induce pulses of insulin secretion by individual islets $[15,72,74]$.

In contrast to the first phase, most $\left[\mathrm{Ca}^{2+}\right]_{\mathrm{c}}$ oscillations that occur during the second phase are not well synchronised between islets, even from the same mouse (Fig. 4a, lower two traces), so that average $\left[\mathrm{Ca}^{2+}\right]_{\mathrm{c}}$ only shows dampened and irregular fluctuations (Fig. 4b). Pooling data from several islets thus largely masks the characteristic pulsatility of insulin secretion, which, nevertheless, has occasionally been measured [75] or disclosed by deconvolution [76] in groups of perifused islets, and persists in the intact pancreas through unidentified synchronising mechanisms [72, 74, 77].

Pulsatility of insulin secretion by individual islets requires synchronisation of the triggering signal in all beta cells. Whereas $\left[\mathrm{Ca}^{2+}\right]_{c}$ oscillations are asynchronous be- 
tween isolated beta cells and between clusters, even when these originate from the same islet [78], they are well synchronised throughout each cluster or each islet, owing to the electrical coupling of beta cells [79] via gap junctions made of connexin36 [80]. When gap junctions are disrupted by knockout of connexin36, the islets no longer display oscillations of $\left[\mathrm{Ca}^{2+}\right]_{\mathrm{c}}$ and insulin secretion [81]. Time (minute-to-minute) regulation of insulin secretion is mainly achieved by variations in the triggering $\mathrm{Ca}^{2+}$ signal, which is not incompatible with the possibility that metabolic oscillations occur simultaneously with, or even cause, $\left[\mathrm{Ca}^{2+}\right]_{\mathrm{c}}$ oscillations $[73,74]$. This question will be discussed further in the next section.

Averaging $\left[\mathrm{Ca}^{2+}\right]_{\mathrm{c}}$ may also lead to a misinterpretation of the regulation of the second phase. Figure 5a shows the mean $\left[\mathrm{Ca}^{2+}\right]_{\mathrm{c}}$ changes measured in 37 islets from four mice when the glucose concentration is raised from 10 to $15 \mathrm{mmol} / \mathrm{l}$. Average $\left[\mathrm{Ca}^{2+}\right]_{\mathrm{c}}$ is increased by about $45 \mathrm{nmol} / \mathrm{l}$. One seemingly logical interpretation of these results, and of the dose-response curves shown in Fig. 2, would be that $15 \mathrm{mmol} / 1$ glucose causes a larger $\left[\mathrm{Ca}^{2+}\right]_{\mathrm{c}}$ rise in each beta cell. However, mere examination of $\left[\mathrm{Ca}^{2+}\right]_{\mathrm{c}}$ changes in individual islets indicates that this conclusion is incorrect (Fig. 5b). In a minority of islets, the oscillations of $\left[\mathrm{Ca}^{2+}\right]_{\mathrm{c}}$ that occur in $10 \mathrm{mmol} / \mathrm{l}$ glucose are replaced by a steady elevation that is not higher than the peak of $\left[\mathrm{Ca}^{2+}\right]_{\mathrm{c}}$ oscillations. In most islets, the oscillations become longer, while their peak barely increases, and the duration of intervals
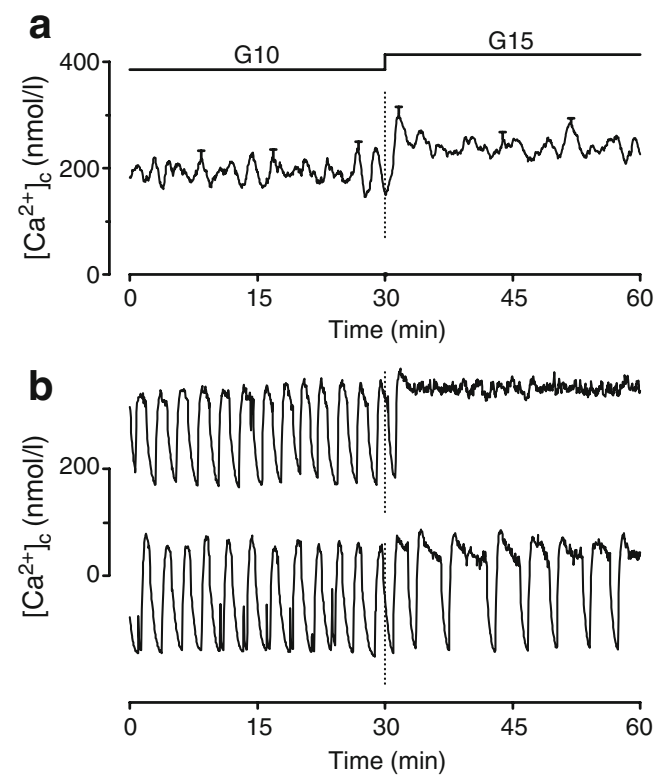

Fig. 5 Effect of an increase in glucose (G) from 10 to $15 \mathrm{mmol} / \mathrm{l}$ on $\left[\mathrm{Ca}^{2+}\right]_{\mathrm{c}}$ in mouse islets. a Mean response $\pm \mathrm{SE}$ for 37 islets from four mice. Note that, for clarity, only some SE bars are shown. b Changes in two representative islets does not significantly change when the glucose concentration is raised to $15 \mathrm{mmol} / \mathrm{l}$. The increase in average islet $\left[\mathrm{Ca}^{2+}\right]_{\mathrm{c}}$ that happens between 10 and $15 \mathrm{mmol} / 1$ glucose (Fig. 5a) does not result from a change in the amplitude of the $\left[\mathrm{Ca}^{2+}\right]_{\mathrm{c}}$ signal, but from an elevation of $\left[\mathrm{Ca}^{2+}\right]_{\mathrm{c}}$ for longer periods of time [82-84]. This is entirely compatible with the effects of glucose on beta cell electrical activity [4,27]. Around the $K_{\mathrm{m}}$, glucose exerts temporal control, not amplitude control, of the triggering signal. The changes are more complex when glucose variations occur within a range of lower concentrations $(7-10 \mathrm{mmol} / \mathrm{l})$ at which the regularity of the $\left[\mathrm{Ca}^{2+}\right]_{\mathrm{c}}$ oscillations is less (compound oscillations) [72, 84]. A slight increase in the amplitude of the oscillations occurs in addition to their lengthening.

\section{Temporal control of second-phase insulin secretion by oscillatory amplifying signals?}

Oscillations of insulin secretion in the presence of a stable triggering $\mathrm{Ca}^{2+}$ signal would imply that amplifying signals oscillate independently of $\left[\mathrm{Ca}^{2+}\right]_{\mathrm{c}}$. Such oscillations of secretion have been reported in batches of rat islets [75]. In single islets from $o b / o b$ mice, small glucose-independent oscillations of insulin secretion (about $2 \%$ of the rate of secretion in $11 \mathrm{mmol} / \mathrm{l}$ glucose) have been detected in the presence of low and stable $\left[\mathrm{Ca}^{2+}\right]_{\mathrm{c}}$, and larger, glucosedependent oscillations were observed in the presence of stably elevated $\left[\mathrm{Ca}^{2+}\right]_{\mathrm{c}}$ [85]. Although we could partly confirm the latter observations in $o b / o b$ mouse islets [86], we never found evidence that the rate of insulin secretion significantly oscillates when $\left[\mathrm{Ca}^{2+}\right]_{\mathrm{c}}$ does not in normal mouse islets [86, 87]. Moreover, imposed metabolic oscillations at stably elevated $\left[\mathrm{Ca}^{2+}\right]_{\mathrm{c}}$ are poorly able to induce pulsatile insulin secretion compared with imposed $\left[\mathrm{Ca}^{2+}\right]_{\mathrm{c}}$ oscillations [88]. This does not mean that metabolic oscillations do not exist. In fact, oscillations of several metabolic events [89-92] and of potential second messengers [49, 92-94] have been detected in individual beta cells or single islets, but they are often associated with $\left[\mathrm{Ca}^{2+}\right]_{\mathrm{c}}$ oscillations. While it is certain that metabolic amplification does not require an oscillatory $\left[\mathrm{Ca}^{2+}\right]_{\mathrm{c}}$ signal (it was first detected when $\left[\mathrm{Ca}^{2+}\right]_{\mathrm{c}}$ was held stable), amplifying signals might be oscillatory $[49,56]$. Appropriate temporal coordination of these signals with $\left[\mathrm{Ca}^{2+}\right]_{\mathrm{c}}$ oscillations could ensure optimal effects on insulin secretion.

\section{Amplitude modulation of second-phase insulin secretion}

Reducing the magnitude of the $\left[\mathrm{Ca}^{2+}\right]_{\mathrm{c}}$ rise during second phase decreases insulin secretion [59]. Augmenting the amplitude of imposed $\left[\mathrm{Ca}^{2+}\right]_{\mathrm{c}}$ oscillations in the presence of 
stable glucose increases insulin secretion [95]. Amplitude modulation of second phase can thus be achieved by changes in $\left[\mathrm{Ca}^{2+}\right]_{\mathrm{c}}$. But how does amplitude modulation of insulin secretion manifest itself during second phase, when the triggering $\left[\mathrm{Ca}^{2+}\right]_{\mathrm{c}}$ signal is mainly subject to temporal control by glucose, as shown above?

In the experiments depicted in Fig. 6, single mouse islets were perifused with diazoxide, to prevent all effects of glucose on beta cell membrane potential, and $\left[\mathrm{Ca}^{2+}\right]_{\mathrm{c}}$ oscillations were imposed by repetitive depolarisation with

a

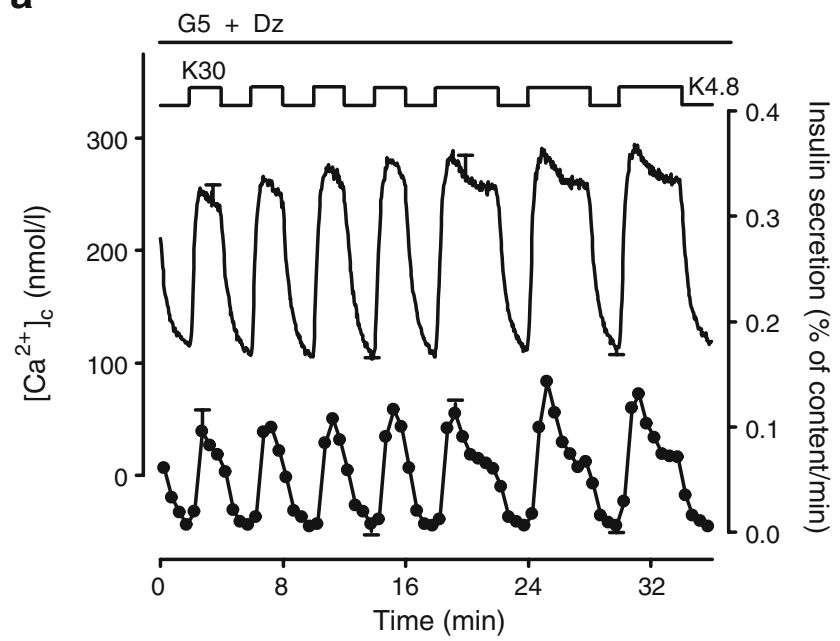

b

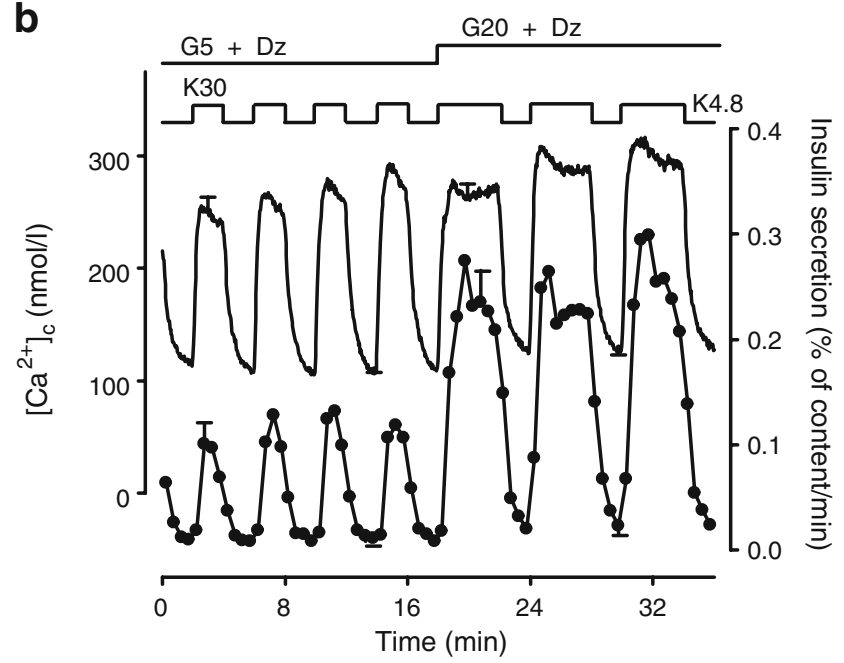

Fig. 6 Temporal control and amplitude modulation of insulin secretion triggered by imposed $\left[\mathrm{Ca}^{2+}\right]_{\mathrm{c}}$ oscillations in mouse islets. The medium contained $100 \mu \mathrm{mol} / 1$ diazoxide $(\mathrm{Dz})$ throughout. The $\mathrm{KCl}$ concentration was increased from 4.8 to $30 \mathrm{mmol} / \mathrm{l}$ (K4.8 and $\mathrm{K} 30$ ) for $2 \mathrm{~min}$ every $4 \mathrm{~min}$, or for $4 \mathrm{~min}$ every $6 \mathrm{~min}$, as indicated. The concentration of glucose was kept constant at $5 \mathrm{mmol} / \mathrm{l}$ (G5) (a) or increased from 5 to $20 \mathrm{mmol} / \mathrm{l}(\mathrm{G} 20)$ as the length of the $\mathrm{KCl}$ pulses was increased (b). $\left[\mathrm{Ca}^{2+}\right]_{\mathrm{c}}$ (continuous traces) and insulin secretion (black circles) were measured in the same single islets, and values were then averaged. Results are means $\pm \mathrm{SE}$ for six islets. Note that, for clarity, only some SE bars are shown. Reproduced from [95]
$30 \mathrm{mmol} / \mathrm{K} \mathrm{KCl}$ [95]. Doubling the duration of the periods of depolarisation doubled the duration of $\left[\mathrm{Ca}^{2+}\right]_{\mathrm{c}}$ oscillations with little impact on their amplitude (Fig. 6), reasonably mimicking the changes occurring spontaneously when the glucose concentration is raised from 10 to $15 \mathrm{mmol} / \mathrm{l}$ (Fig. 5b). Each imposed oscillation of $\left[\mathrm{Ca}^{2+}\right]_{\mathrm{c}}$ triggered a pulse of insulin secretion, which was measured simultaneously. When the glucose concentration was kept constant at $5 \mathrm{mmol} / \mathrm{l}$ throughout the whole experiment, insulin pulses increased in duration when $\left[\mathrm{Ca}^{2+}\right]_{\mathrm{c}}$ oscillations became longer, but they did not change in amplitude (Fig. 6a). In contrast, when the glucose concentration was raised to $20 \mathrm{mmol} / \mathrm{l}$ simultaneously with the imposed lengthening of $\left[\mathrm{Ca}^{2+}\right]_{\mathrm{c}}$ oscillations (to activate the amplifying pathway and therefore mimic both actions of glucose), the amplitude of insulin pulses was also markedly augmented (Fig. 6b). An increase in the amplitude of insulin pulses from single mouse islets also occurs when the concentration of glucose is raised from 10 to $20 \mathrm{mmol} / \mathrm{l}$ at normal $\mathrm{KCl}$ levels $[83,96]$. In conclusion, at the islet level, insulin secretion during the second phase is not stable but pulsatile, and subject to temporal control by variations in the duration of $\left[\mathrm{Ca}^{2+}\right]_{\mathrm{c}}$ oscillations, while amplitude modulation is achieved secondarily by small changes in the magnitude of the triggering signal and primarily through metabolic amplification. It remains unclear how this dual control of individual islets translates in vivo. Thus, we do not know how all islets residing in their normal environment are entrained to produce pulsatile insulin secretion by the whole pancreas and eventually lead to oscillations of plasma insulin levels [72, 74, 77]. Nevertheless, amplitude regulation (increase in pulse mass) is the predominant effect of high glucose in vivo [77].

\section{Heterogeneity of beta cells and amplification of insulin secretion}

Individual beta cells are heterogeneous [42, 80, 97-99]. Dose-response curves such as those shown in Fig. 2 could reflect recruitment of beta cells displaying distinct sensitivities to glucose and responding in an all-or-none fashion once activated. Single beta cells are indeed progressively recruited to produce a triggering $\mathrm{Ca}^{2+}$ signal when stimulated by increasing glucose concentrations [42, 99, 100]. However, this recruitment is restricted to a narrow range of low concentrations $(4-10 \mathrm{mmol} / \mathrm{l})$, and the individual beta cell response is not all-or-none either with glucose or tolbutamide [99, 100]. Moreover, beta cell association and coupling within clusters or intact islets markedly decreases the heterogeneity [72, 74, 99]. Within an intact islet, virtually all beta cells respond simultaneously $[15,81,83]$. The temporal control of $\left[\mathrm{Ca}^{2+}\right]_{\mathrm{c}}$ exerted by 
glucose (Fig. 5) is also incompatible with models attributing the increase in the average triggering $\mathrm{Ca}^{2+}$ signal to the recruitment of individual beta cells with distinct sensitivities to glucose.

Nevertheless, a similar triggering signal in all beta cells of an islet does not necessarily imply homogeneity of the secretory responses. Even though there is less metabolic heterogeneity between beta cells associated within an islet than between dispersed beta cells [98], differences in the production of amplifying signals remain possible. Two beta cells within the same islet could thus secrete insulin at different rates despite a similar triggering signal. This raises the intriguing possibility that the phenomenon of amplification corresponds to the recruitment of poorly secreting beta cells to produce amplifying signals. However, the gradual metabolic amplification observed in single beta cells $[46,47]$ does not support this hypothesis.

\section{Overall quantitative contribution of triggering and amplifying pathways}

Whereas determination of the hierarchy between both pathways is straightforward, estimation of the proportion of glucose-induced insulin secretion that is attributable to each pathway is more problematic and necessarily indirect. It is based on quantitative comparisons of insulin secretion in response to a similar rise in $\left[\mathrm{Ca}^{2+}\right]_{\mathrm{c}}$ in the absence and presence of amplification. It should be noted, however, that the amplification of insulin secretion by glucose is relatively weak when $\left[\mathrm{Ca}^{2+}\right]_{\mathrm{c}}$ is only moderately increased above basal values, and becomes more prominent when the elevation of $\left[\mathrm{Ca}^{2+}\right]_{\mathrm{c}}$, is larger, be it sustained or oscillatory $[87,95]$. Nevertheless, from comparisons such as those in Fig. 3, and others using several distinct protocols [38, 44, 87, 95], it appears that amplification accounts for at least $50 \%$ of insulin secretion during the second phase. Figure 3 suggests that the contribution of amplification to the first phase may also be about $50 \%$. However, further experiments comparing the first phases of elevations in $\left[\mathrm{Ca}^{2+}\right]_{\mathrm{c}}$ and insulin secretion in response to different tolbutamide and glucose concentrations are necessary to verify this estimation. Nevertheless, although the metabolic amplifying pathway is second to the triggering pathway in the hierarchy, its quantitative contribution to both phases is by no means trivial.

\section{Conclusions}

There are more similarities than differences between the first and second phases of glucose-induced insulin secretion. Both are subject to the same dual hierarchical control. The essential triggering $\mathrm{Ca}^{2+}$ signal exerts both temporal and amplitude control of the response, but the modulation of amplitude is mainly achieved by the metabolic amplifying pathway. When biphasic insulin secretion is considered over its physiological duration of several minutes, the time course of $\left[\mathrm{Ca}^{2+}\right]_{\mathrm{c}}$ changes in beta cells is certainly as important as the distribution of insulin granules in different pools to shape the response. Common views of the second phase also need revision. It is not a sustained secretory response to a monotonic stimulus whose amplitude increases with the glucose concentration. It is caused by a succession of large increases in $\left[\mathrm{Ca}^{2+}\right]_{\mathrm{c}}$ that are subject to a dual regulation (time and efficacy) by glucose. The second phase could be viewed as iterations of the first phase.

Acknowledgements I am grateful to all students, post-docs and technicians, and to the many colleagues and collaborators who inspired and contributed to my studies of the islets of Langerhans over the years. I particularly wish to thank M. Nenquin, P. Gilon, J. C. Jonas and J. Rahier. My research work has been made possible by the continuous financial support of the Université Catholique de Louvain, the Fonds National de la Recherche Scientifique in Brussels, the Direction de la Recherche Scientifique de la Communauté Française de Belgique, and the Politique Scientifique Fédérale belge.

Duality of interest The author declares that there is no duality of interest associated with this manuscript.

\section{References}

1. Grodsky GM, Batts AA, Bennett LL, Vcella C, McWilliams NB, Smith DF (1963) Effects of carbohydrates on secretion of insulin from isolated rat pancreas. Am J Physiol 205:638-644

2. Coore HG, Randle PJ (1964) Regulation of insulin secretion studied with pieces of rabbit pancreas incubated in vitro. Biochem J 93:66-78

3. Dean PM, Matthews EK (1968) Electrical activity in pancreatic islet cells. Nature 219:389-390

4. Henquin JC, Meissner HP (1984) Significance of ionic fluxes and changes in membrane potential for stimulus-secretion coupling in pancreatic B cells. Experientia 40:1043-1052

5. Malaisse WJ (1996) Metabolic signaling of insulin secretion. Diabetes Rev 4:145-159

6. Ashcroft FM, Rorsman P (1989) Electrophysiology of the pancreatic $\beta$-cell. Prog Biophys Mol Biol 54:87-143

7. Seino S, Iwanaga T, Nagashima K, Miki T (2000) Diverse roles of $K_{\text {ATP }}$ channels learned from Kir6.2 genetically engineered mice. Diabetes 49:311-318

8. Henquin JC (2000) The triggering and amplifying pathways of the regulation of insulin secretion by glucose. Diabetes 49:1751-1760

9. Maechler P, Wollheim CB (2001) Mitochondrial function in normal and diabetic beta-cells. Nature 414:807-812

10. Bryan J, Vila-Carriles WH, Zhao G, Babenko AP, Aguilar-Bryan L (2004) Toward linking structure with function in ATP-sensitive $\mathrm{K}^{+}$channels. Diabetes 53(Suppl 3):S104-S112

11. Tarasov A, Dusonchet J, Ashcroft F (2004) Metabolic regulation of the pancreatic beta cell ATP-sensitive $\mathrm{K}^{+}$channel: a pas de deux. Diabetes 53(Suppl 3):S113-S122

12. Nichols CG (2006) $\mathrm{K}_{\mathrm{ATP}}$ channels as molecular sensors of cellular metabolism. Nature 440:470-476 
13. Gembal M, Gilon P, Henquin JC (1992) Evidence that glucose can control insulin release independently from its action on ATPsensitive $\mathrm{K}^{+}$channels in mouse B cells. J Clin Invest 89:1288-1295

14. Sato Y, Aizawa T, Komatsu M, Okada N, Yamada T (1992) Dual functional role of membrane depolarization $/ \mathrm{Ca}^{2+}$ influx in rat pancreatic B cell. Diabetes 41:438-443

15. Henquin JC, Ravier MA, Nenquin M, Jonas JC, Gilon P (2003) Hierarchy of the beta cell signals controlling insulin secretion. Eur J Clin Invest 33:742-750

16. Detimary P, Van den Berghe G, Henquin JC (1996) Concentration dependence and time course of the effects of glucose on adenine and guanine nucleotides in mouse pancreatic islets. $\mathrm{J}$ Biol Chem 271:20559-20565

17. Lang J (1999) Molecular mechanisms and regulation of insulin exocytosis as a paradigm of endocrine secretion. Eur J Biochem 259:3-17

18. Rorsman P, Renstrom E (2003) Insulin granule dynamics in pancreatic $\beta$-cells. Diabetologia 46:1029-1045

19. Lovis P, Gattesco S, Regazzi R (2008) Regulation of the expression of components of the exocytotic machinery of insulin-secreting cells by microRNAs. Biol Chem 389:305-312

20. Gauthier BR, Wollheim CB (2008) Synaptotagmins bind calcium to release insulin. Am J Physiol Endocrinol Metab 295:E1279E1286

21. Henquin JC (2004) Pathways in beta-cell stimulus-secretion coupling as targets for therapeutic insulin secretagogues. Diabetes 53(Suppl 3):S48-S58

22. Gribble FM, Reimann F (2003) Sulphonylurea action revisited: the post-cloning era. Diabetologia 46:875-891

23. Seghers V, Nakazaki M, DeMayo F, Aguilar-Bryan L, Bryan J (2000) Surl knockout mice. A model for $\mathrm{K}_{\text {ATP }}$ channelindependent regulation of insulin secretion. J Biol Chem 275:9270-9277

24. Nenquin M, Szollosi A, Aguilar-Bryan L, Bryan J, Henquin JC (2004) Both triggering and amplifying pathways contribute to fuel-induced insulin secretion in the absence of sulfonylurea receptor-1 in pancreatic $\beta$-cells. J Biol Chem 279:32316-32324

25. Miki T, Nagashima K, Tashiro $F$ et al (1998) Defective insulin secretion and enhanced insulin action in $\mathrm{K}_{\mathrm{ATP}}$ channel-deficient mice. Proc Natl Acad Sci U S A 95:10402-10406

26. Ravier MA, Nenquin M, Miki T, Seino S, Henquin JC (2009) Glucose controls cytosolic $\mathrm{Ca}^{2+}$ and insulin secretion in mouse islets lacking ATP-sensitive $\mathrm{K}^{+}$channels owing to a knockout of the pore-forming subunit Kir6.2. Endocrinology 150:33-45

27. Henquin JC (1988) ATP-sensitive $\mathrm{K}^{+}$channels may control glucose-induced electrical activity in pancreatic B cells. Biochem Biophys Res Commun 156:769-775

28. Panten U, Schwanstecher M, Wallasch A, Lenzen S (1988) Glucose both inhibits and stimulates insulin secretion from isolated pancreatic islets exposed to maximally effective concentrations of sulfonylureas. Naunyn Schmiedebergs Arch Pharmacol 338:459-462

29. Gembal M, Detimary P, Gilon P, Gao ZY, Henquin JC (1993) Mechanisms by which glucose can control insulin release independently from its action on ATP-sensitive $\mathrm{K}^{+}$channels in mouse B cells. J Clin Invest 91:871-880

30. Dufrane D, Nenquin M, Henquin JC (2007) Nutrient control of insulin secretion in perifused adult pig islets. Diabetes Metab $33: 430-438$

31. Straub SG, James RFL, Dunne MJ, Sharp GWG (1998) Glucose activates both $\mathrm{K}_{\mathrm{ATP}}$ channel-dependent and $\mathrm{K}_{\mathrm{ATP}}$ channelindependent signaling pathways in human islets. Diabetes 47:758-763

32. Henquin JC, Dufrane D, Nenquin M (2006) Nutrient control of insulin secretion in isolated normal human islets. Diabetes 55:3470-3477
33. Hohmeier HE, Mulder H, Chen G, Henkel-Rieger R, Prentki M, Newgard CB (2000) Isolation of INS-1-derived cell lines with robust ATP-sensitive $\mathrm{K}^{+}$channel-dependent and -independent glucose-stimulated insulin secretion. Diabetes 49:424-430

34. Straub SG, Sharp GW (2002) Glucose-stimulated signaling pathways in biphasic insulin secretion. Diabetes Metab Res Rev 18:451-463

35. Szollosi A, Nenquin M, Aguilar-Bryan L, Bryan J, Henquin JC (2007) Glucose stimulates $\mathrm{Ca}^{2+}$ influx and insulin secretion in 2week-old $\beta$-cells lacking ATP-sensitive $\mathrm{K}^{+}$channels. J Biol Chem 282:1747-1756

36. Komatsu M, Schermerhorn T, Aizawa T, Sharp GW (1995) Glucose stimulation of insulin release in the absence of extracellular $\mathrm{Ca}^{2+}$ and in the absence of any increase in intracellular $\mathrm{Ca}^{2+}$ in rat pancreatic islets. Proc Natl Acad Sci U S A 92:10728-10732

37. Sato Y, Nenquin M, Henquin JC (1998) Relative contribution of $\mathrm{Ca}^{2+}$-dependent and $\mathrm{Ca}^{2+}$-independent mechanisms to the regulation of insulin secretion by glucose. FEBS Lett 421:115-119

38. Ishiyama N, Ravier MA, Henquin JC (2006) Dual mechanism of the potentiation by glucose of insulin secretion induced by arginine and tolbutamide in mouse islets. Am J Physiol Endocrinol Metab 290:E540-E549

39. Hermans MP, Schmeer W, Henquin JC (1987) The permissive effect of glucose, tolbutamide and high $\mathrm{K}^{+}$on arginine stimulation of insulin release in isolated mouse islets. Diabetologia 30:659-665

40. Pfeifer MA, Halter JB, Porte D Jr (1981) Insulin secretion in diabetes mellitus. Am J Med 70:579-588

41. Henquin JC, Nenquin M, Stiernet P, Ahren B (2006) In vivo and in vitro glucose-induced biphasic insulin secretion in the mouse: pattern and role of cytoplasmic $\mathrm{Ca}^{2+}$ and amplification signals in $\beta$-cells. Diabetes 55:441-451

42. Heart E, Corkey RF, Wikstrom JD, Shirihai OS, Corkey BE (2006) Glucose-dependent increase in mitochondrial membrane potential, but not cytoplasmic calcium, correlates with insulin secretion in single islet cells. Am J Physiol Endocrinol Metab 290:E143-E148

43. Bertrand G, Ishiyama N, Nenquin M, Ravier MA, Henquin JC (2002) The elevation of glutamate content and the amplification of insulin secretion in glucose-stimulated pancreatic islets are not causally related. J Biol Chem 277:32883-32891

44. Stiernet P, Guiot Y, Gilon P, Henquin JC (2006) Glucose acutely decreases $\mathrm{pH}$ of secretory granules in mouse pancreatic islets. Mechanisms and influence on insulin secretion. J Biol Chem 281:22142-22151

45. Detimary P, Gilon P, Nenquin M, Henquin JC (1994) Two sites of glucose control of insulin release with distinct dependence on the energy state in pancreatic B cells. Biochem J 297:455-461

46. Eliasson L, Renström E, Ding WG, Proks P, Rorsman P (1997) Rapid ATP-dependent priming of secretory granules precedes $\mathrm{Ca}^{2+}$ induced exocytosis in mouse pancreatic $\beta$-cells. J Physiol 503:399-412

47. Takahashi N, Kadowaki T, Yazaki Y, Ellis-Davies GCR, Miyashita Y, Kasai H (1999) Post-priming actions of ATP on $\mathrm{Ca}^{2+}$-dependent exocytosis in pancreatic beta cells. Proc Natl Acad Sci U S A 96:760-765

48. Jensen MV, Joseph JW, Ronnebaum SM, Burgess SC, Sherry AD, Newgard CB (2008) Metabolic cycling in control of glucose-stimulated insulin secretion. Am J Physiol Endocrinol Metab 295:E1287-E1297

49. Dyachok O, Idevall-Hagren O, Sågetorp J et al (2008) Glucoseinduced cyclic AMP oscillations regulate pulsatile insulin secretion. Cell Metab 8:26-37

50. Ivarsson R, Quintens R, Dejonghe S, Tsukamoto K, in't Veld P, Renström E, Schuit FC (2005) Redox control of exocytosis: regulatory role of $\mathrm{NADPH}$, thioredoxin, and glutaredoxin. Diabetes 54:2132-2142 
51. Panten U, Rustenbeck I (2008) Fuel-induced amplification of insulin secretion in mouse pancreatic islets exposed to a high sulfonylurea concentration: role of the NADPH/NADP ${ }^{+}$ratio. Diabetologia 51:101-109

52. Gunawardana SC, Liu YJ, MacDonald MJ, Straub SG, Sharp GW (2004) Anaplerotic input is sufficient to induce timedependent potentiation of insulin release in rat pancreatic islets. Am J Physiol Endocrinol Metab 287:E828-E833

53. Rutter GA, Leclerc I (2009) The AMP-regulated kinase family: enigmatic targets for diabetes therapy. Mol Cell Endocrinol 297:41-49

54. Varadi A, Ainscow EK, Allan VJ, Rutter GA (2002) Involvement of conventional kinesin in glucose-stimulated secretory granule movements and exocytosis in clonal pancreatic betacells. J Cell Sci 115:4177-4189

55. Bertuzzi A, Salinari S, Mingrone G (2007) Insulin granule trafficking in beta-cells: mathematical model of glucose-induced insulin secretion. Am J Physiol Endocrinol Metab 293:E396-E409

56. Chen YD, Wang S, Sherman A (2008) Identifying the targets of the amplifying pathway for insulin secretion in pancreatic betacells by kinetic modeling of granule exocytosis. Biophys $\mathrm{J}$ 95:2226-2241

57. Cerasi E, Luft R (1967) The plasma insulin response to glucose infusion in healthy subjects and in diabetes mellitus. Acta Endocrinol 55:278-304

58. Curry DL, Bennett LL, Grodsky GM (1968) Dynamics of insulin secretion by the perfused rat pancreas. Endocrinology 83:572-584

59. Henquin JC, Ishiyama N, Nenquin M, Ravier MA, Jonas JC (2002) Signals and pools underlying biphasic insulin secretion. Diabetes 51(Suppl 1):S60-S67

60. Luzi L, DeFronzo RA (1989) Effect of loss of first-phase insulin secretion on hepatic glucose production and tissue glucose disposal in humans. Am J Physiol 257:E241-E246

61. Nesher R, Cerasi E (2002) Modeling phasic insulin release. Immediate and time-dependent effects of glucose. Diabetes 51 (Suppl. 1):S53-S59

62. Nunemaker CS, Wasserman DH, McGuinness OP, Sweet IR, Teague JC, Satin LS (2006) Insulin secretion in the conscious mouse is biphasic and pulsatile. Am J Physiol Endocrinol Metab 290:E523-E529

63. O'Connor MD, Landahl H, Grodsky GM (1980) Comparison of storage- and signal-limited models of pancreatic insulin secretion. Am J Physiol 238:R378-R389

64. Jing X, Li DQ, Olofsson CS, Salehi A et al (2005) CaV2.3 calcium channels control second-phase insulin release. J Clin Invest 115:146-154

65. Fridlyand LE, Tamarina N, Philipson LH (2003) Modeling of $\mathrm{Ca}^{2+}$ flux in pancreatic beta-cells: role of the plasma membrane and intracellular stores. Am J Physiol Endocrinol Metab 285:E138E154

66. Komatsu M, Sato Y, Aizawa T, Hashizume K (2001) $\mathrm{K}_{\text {ATP }}$ channel-independent glucose action: an elusive pathway in stimulus-secretion coupling of pancreatic beta-cell. Endocr J 48:275-288

67. Shibasaki T, Takahashi H, Miki T et al (2007) Essential role of Epac2/Rap1 signaling in regulation of insulin granule dynamics by cAMP. Proc Natl Acad Sci U S A 104:19333-19338

68. Kasai K, Fujita T, Gomi H, Izumi T (2008) Docking is not a prerequisite but a temporal constraint for fusion of secretory granules. Traffic 9:1191-203

69. Barg S, Olofsson CS, Schriever-Abeln J et al (2002) Delay between fusion pore opening and peptide release from large dense-core vesicles in neuroendocrine cells. Neuron 33:287-299

70. Ohara-Imaizumi M, Fujiwara T, Nakamichi Y et al (2007) Imaging analysis reveals mechanistic differences between firstand second-phase insulin exocytosis. J Cell Biol 177:695-705
71. Lenzen S (1978) The immediate insulin-secretory response of the rat pancreas to glucose compared with tolbutamide and other secretagogues. Diabetes 27:27-34

72. Gilon P, Ravier MA, Jonas JC, Henquin JC (2002) Control mechanisms of the oscillations of insulin secretion in vitro and in vivo. Diabetes 51(Suppl 1):144-151

73. Bertram R, Sherman A, Satin LS (2007) Metabolic and electrical oscillations: partners in controlling pulsatile insulin secretion. Am J Physiol Endocrinol Metab 293:E890-E900

74. Tengholm A, Gylfe E (2009) Oscillatory control of insulin secretion. Mol Cell Endocrinol 297:58-72

75. Cunningham BA, Deeney JT, Bliss CR, Corkey BE, Tornheim K (1996) Glucose-induced oscillatory insulin secretion in perifused rat pancreatic islets and clonal beta-cells (HIT). Am J Physiol Endocrinol Metab 271:E702-E710

76. Song SH, Kjems L, Ritzel R et al (2002) Pulsatile insulin secretion by human pancreatic islets. J Clin Endocrinol Metab $87: 213-221$

77. Pørksen N (2002) The in vivo regulation of pulsatile insulin secretion. Diabetologia 45:3-20

78. Zarkovic M, Henquin JC (2004) Synchronization and entrainment of cytoplasmic $\mathrm{Ca}^{2+}$ oscillations in cell clusters prepared from single or multiple mouse pancreatic islets. Am J Physiol Endocrinol Metab 287:E340-E347

79. Meissner HP (1975) Electrophysiological evidence for coupling between beta cells of pancreatic islets. Nature 262:502-504

80. Bavamian S, Klee P, Britan A et al (2007) Islet-cell-to-cell communication as basis for normal insulin secretion. Diabetes Obes Metab 9(Suppl 2):118-132

81. Ravier MA, Guldenagel M, Charollais A et al (2005) Loss of connexin 36 channels alters $\beta$-cell coupling, islet synchronization of glucose-induced $\mathrm{Ca}^{2+}$ and insulin oscillations, and basal insulin release. Diabetes 54:1798-1807

82. Santos RM, Rosario LM, Nadal A, Garcia-Sancho J, Soria B, Valdeolmillos M (1991) Widespread synchronous $\left[\mathrm{Ca}^{2+}\right]_{\mathrm{i}}$ oscillations due to bursting electrical activity in single pancreatic islets. Pflugers Arch 418:417-422

83. Gilon P, Henquin JC (1995) Distinct effects of glucose on the synchronous oscillations of insulin release and cytoplasmic $\mathrm{Ca}^{2+}$ concentration measured simultaneously in single mouse islets. Endocrinology 136:5725-5730

84. Nunemaker CS, Bertram R, Sherman A, Tsaneva-Atanasova K, Daniel CR, Satin LS (2006) Glucose modulates $\left[\mathrm{Ca}^{2+}\right]_{\mathrm{i}}$ oscillations in pancreatic islets via ionic and glycolytic mechanisms. Biophys J 91:2082-2096

85. Westerlund J, Ortsäter H, Palm F, Sundsten T, Bergsten P (2001) Glucose-regulated pulsatile insulin release from mouse islets via the $\mathrm{K}_{\text {ATP }}$ channel-independent pathway. Eur J Endocrinol 144:667-675

86. Kjems LL, Ravier MA, Jonas JC, Henquin JC (2002) Do oscillations of insulin secretion occur in the absence of cytoplasmic $\mathrm{Ca}^{2+}$ oscillations in beta-cells. Diabetes 51(Suppl 1):S177-S182

87. Jonas JC, Gilon P, Henquin JC (1998) Temporal and quantitative correlations between insulin secretion and stably elevated or oscillatory cytoplasmic $\mathrm{Ca}^{2+}$ in mouse pancreatic beta cells. Diabetes 47:1266-1273

88. Ravier M, Gilon P, Henquin JC (1999) Oscillations of insulin secretion can be triggered by imposed oscillations of cytoplasmic $\mathrm{Ca}^{2+}$ or metabolism in normal mouse islets. Diabetes 48:2374 2382

89. Longo EA, Tornheim K, Deeney JT et al (1991) Oscillations in cytosolic free $\mathrm{Ca}^{2+}$, oxygen consumption, and insulin secretion in glucose-stimulated rat pancreatic islets. J Biol Chem 266:9314-9319

90. Krippeit-Drews P, Düfer M, Drews G (2000) Parallel oscillations of intracellular calcium activity and mitochondrial membrane potential in mouse pancreatic B cells. Biochem Biophys Res Commun 267:179-813 
91. Kennedy RT, Kauri LM, Dahlgren GM, Jung SK (2002) Metabolic oscillations in beta cells. Diabetes 51(Suppl 1):S152-S161

92. Luciani DS, Misler S, Polonsky KS (2006) $\mathrm{Ca}^{2+}$ controls slow $\mathrm{NAD}(\mathrm{P}) \mathrm{H}$ oscillations in glucose-stimulated mouse pancreatic islets. J Physiol 572:379-392

93. Ainscow EK, Rutter GA (2002) Glucose-stimulated oscillations in free cytosolic ATP concentration imaged in single islet betacells: evidence for a $\mathrm{Ca}^{2+}$-dependent mechanism. Diabetes 51 (Suppl 1):S162-S170

94. Tamarina NA, Kuznetsov A, Rhodes CJ, Bindokas VP, Philipson LH (2005) Inositol (1,4,5)-trisphosphate dynamics and intracellular calcium oscillations in pancreatic beta-cells. Diabetes 54:30733081

95. Ravier MA, Henquin JC (2002) Time and amplitude regulation of pulsatile insulin secretion by triggering and amplifying pathways in mouse islets. FEBS Lett 530:215-219
96. Bergsten P, Hellman B (1993) Glucose-induced amplitude regulation of pulsatile insulin secretion from individual pancreatic islets. Diabetes 42:670-674

97. Pipeleers DG (1992) Heterogeneity in pancreatic $\beta$ cell population. Diabetes 41:777-781

98. Bennett BD, Jetton TL, Ying G, Magnuson MA, Piston DW (1996) Quantitative subcellular imaging of glucose metabolism within intact pancreatic islets. J Biol Chem 271:3647-3651

99. Jonkers FC, Henquin JC (2001) Measurements of cytoplasmic $\mathrm{Ca}^{2+}$ in islet cell clusters show that glucose rapidly recruits $\beta$ cells and gradually increases the individual cell response. Diabetes 50:540-550

100. Jonkers FC, Guiot Y, Rahier J, Henquin JC (2001) Tolbutamide stimulation of pancreatic $\beta$-cells involves both cell recruitment and increase in the individual $\mathrm{Ca}^{2+}$ response. $\mathrm{Br} \mathrm{J}$ Pharmacol $133: 575-585$ 